\title{
The Use of an Open Access Corpus Web Tool in a DDL Writing Model
}

\author{
by
}

\section{Prof. Mohamed Said Negm}

English Language Department, Faculty of Arts, Tanta University \&

\section{Waleed Saad Mandour}

English Language Department, The International Institute for Languages

\section{Abstract}

This study aims at presenting a writing model that incorporates the DataDriven Learning (DDL) method in classroom teaching suitable for tertiary-level students. The model teaching setting benefits mainly from the preloaded online corpora, freely available at skell.sketchengine.eu (Baisa \& Suchomel, 2014). It supports the English language learners with authentic texts whereby they can adopt reliably in their productive writing. The proposed web tool enables a multi-layer searching feature of which the student, as a researcher, can easily check how a particular word or phrase is used by native speakers of English. The study takes into account Scrivener's writing framework (2011) pedagogically in developing our DDL-based-writing model. Findings, so far, enhance the learners' phraseological production as the online source provides formulaic expressions (collocations) and semantic relations (synonyms) in real contexts. Results, in addition, promote learner autonomy, besides developing indirectly the digital skills as required in the 21 st century. Further, the pedagogical implications of the proposed model would encourage curriculum designers to actively integrate corpora use.

Keywords: DDL, Corpus Studies, Discovery Learning, EAP, Learner Autonomy 


\section{The Use of an Open Access Corpus Web Tool in a DDL Writing Model}

استخدام أداة ويب متاحة للجميع في نموذج لتعليم الكتابة على أسس استياق المعلومات

\section{الملخص العربى}

تهدف الدراسة الى تقديم نموذج لتعليم مهارة الكتابة على أسس منهج استياق المعلومات

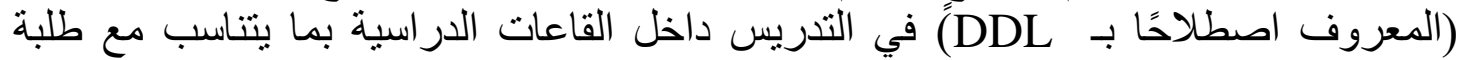
المرحلة الجامعية. حيث يستفيد نموذج تدريس الكتابة في الأساس من الأخائر اللغوية المتاحة

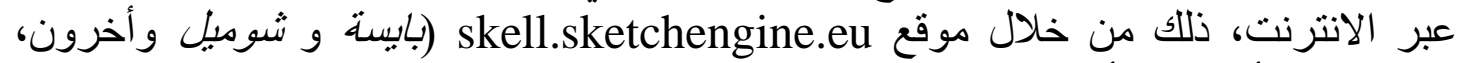

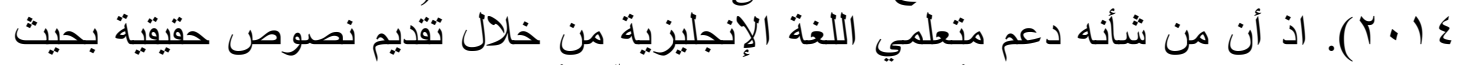

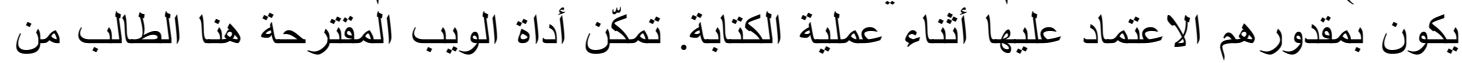

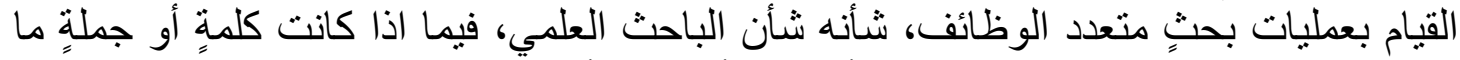

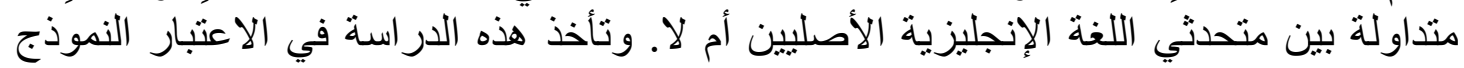

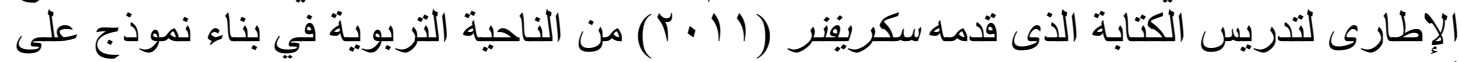

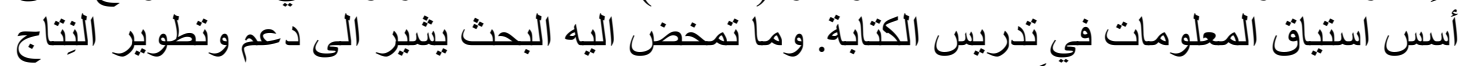

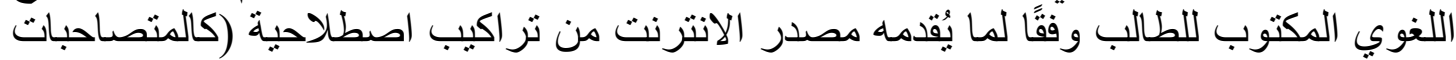

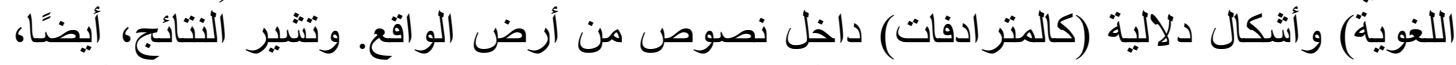

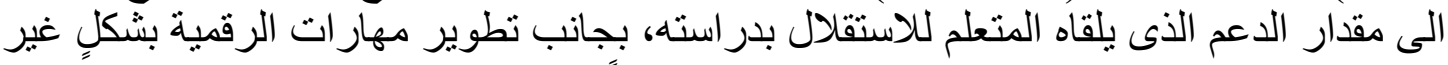

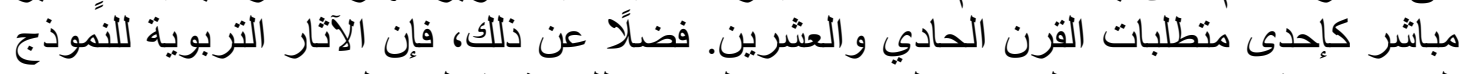
المقترح ستشجع مصدمي المناهج على استخدام الذخائر اللغوية بشكلٍ فعّال.

الكلمات الدفتاحية: دراسات الذخائر اللغوية، التعلّم بالاستكثاف، اللغة الإنجليزية للأغراض الأكاديمبية، استقلات المفناهن المتعلم 


\section{Introduction}

Writing, as a productive skill in language learning, represents a cornerstone of classroom teaching/learning in which English Language Learners' accumulated knowledge is actively and thoughtfully integrated. There is a variety of strategies and methods of delivery that leads pedagogically to a successful reflection of the language items (vocabulary, grammar, etc.) through writing. However, students may commit errors that hinder the fluidity and nativity of the written text, even for advanced levels ( (Schmitt, Sonbul, Vilkaitè-Lozdienè, \& Macis, 2013). Hyland (2008) and Schmitt (2012) argued that EFL learners mostly lack the right phraseological knowledge required to produce native-like L2 production. Accordingly, no wonder the literature (e.g. Hyland, 2006; Durrant \& Schmitt, 2009) confirms the fact that EFL/ESP learners tend to underuse or misuse the formulaic expressions due to insufficient knowledge and classroom practice, even at higher education levels. Lexicographers, such as Kilgarriff et al., claimed that dictionary knowledge of learned vocabulary should be supplemented by careful adoption of authentic texts to help students acquire intuitively how to use lexical items in contexts (2016, pp. 61-80).

Thus, we propose in our paper a model for in-classroom writing that exploits the advantages of corpus studies and the promising potentials of the Data-Driven Learning approach (DDL) pioneered by Tim Johns (1991). We start by reviewing previous studies in DDL and corpus studies and discuss the possible challenges of bringing that corpus approach to class. Then, we introduce the features of the Sketch Engine for Language Learners (SKELL) free online tool designed for language learners as described by Kilgarriff et al. (2014 \& 2016). After that, we present a DDL writing model in which the discovery learning method (also called inductive learning), is adapted herewith. Eventually, possible difficulties and concerns about the suggested DDL model are discussed. Most importantly, however, what we present in the paper as a classroom approach that incorporates technology is suitable for low-tech classrooms as well as being teacher/student-friendly.

1. Literature Review

\subsection{Current Challenges in EAP Writing Classes}

By keeping the grammatical and graphical errors aside, L2 learners tend to make other writing errors in terms of sentence phraseology. Different studies have discussed the issue thoroughly and suggested various correction techniques. The difficulty in EAP writing classrooms is attributable to the disciplinary specificity of the language content produced by university learners (Flowerdew \& Costley, 2016). Hyland (2006) revealed the distinction of teaching EGP (English for General 
Purposes) \& ESP/EAP for that the latter is bound to specific forms of linguistic patterns whereby people encode their communicated datasets to their peers in the academe. In other words, teaching Academic writing entails three main register scopes to study and practice: high lexical density (a significant use of open class/content words vs close class/grammatical words), high nominal style (presenting actions and events in nouns rather than verbs), and impersonal constructions (Hyland, 2006, pp. 9-15).

The mundane challenge Hyland claimed is the fact many EAP teachers fail to decontextualize the academic life in their language classes. They are not concerned much with developing research concepts and methods for instance (2006, p. 15). In reference to EAP writing, certain skills should be established to empower students with the relevant genre analysis and textual and linguistic scrutiny via providing EAP course designs and teaching methodologies/strategies promoting academic literacy and centrality. One of those solutions exists in adopting the datadriven learning approach (Hyland, 2006 \& 2016).

2.2. Data-Driven Learning in Classroom Teaching

Data-Driven Learning (DDL) is defined in the Encyclopedia of Applied Linguistics as "the approach of bringing the use of corpora to language classrooms for that learners learn best when they "discover" the language in the same way that corpus linguists do". Tribble stressed the genuine aspect of DDL as a framework that "offers a means whereby students can take a control on their own learning" (Tribble, 2013, p. 1175). Likewise, using corpora in an EFL classroom increases collaboration and group discussions (Anthony, Flowerdew, \& Costley, Introducing corpora and corpus tools into the technical writing classroom through Data-Driven Learning (DDL), 2016, p. 164) which is intrinsically one of the four skills to build and acquire in the 21 st century.

Since the 1st call for adopting the corpus approach in classroom teaching by Tim John, more than three decades ago (Johns, 1994), there have been numerous empirical studies to prove how versatile it is. They mostly advocate the idea of empowering apprentices with the right tool to develop intuitively their vocabulary and grammatical conceptualization (see for example Koosha \& Jafarpour, 2006). And in a more recent study, Antony (2019) argued the merits in both language levels: disciplinespecific level (i.e. ESP) and discipline-common (i.e. EAP, what the current paper is concerned about). He illustrated that the DDL approach stimulates higher thinking skills, such as critical thinking and problemsolving ones (Anthony, 2019, pp. 233-234). 
In spite of that, no curriculum or teaching resource includes structurally that innovative approach. Scrivener's Learning Teaching (2011), for instance, neglects to discuss it. Instead, it expounds minimally upon using corpora for researchers to see the level of the ubiquity of a formulaic pattern; it gives an example of the difference between different from and different to (p. 346). Passing such knowledge to the students, however, is never deliberated over. In that globally acknowledged reference for language teachers, Scrivener described his exclusive inclusion of the "nononsense approaches" in his book (Scrivener, 2014).

There is a number of worth benefits for adopting the DDL approach in classroom settings, especially in teaching writing. We list them as follows.

It provides inductive learning experience (Silver, Dewing, \& Perini, 2012; Mao, Liu, \& Zhang, 2018, p. 1162). It grows inferencing and evidence-gathering skills required in presenting quality pieces of writing by L2 students.

It offers a "corrective function" (Gilquin \& Granger, 2010, p. 359), which enables L2 learners to compare their production with native writers'.

It promotes learner autonomy: once students are introduced to how to use the corpus tool, they can use autonomously outside the classroom on any smart device with a decent internet connection.

It supports the learner's rejection of his/her fossilized error (Nesselhauf, 2004 , p. 140). When they are exposed to excerpts (40 examples in SKELL) written by native-English speakers, enough evidence is given for correction.

It triggers students' inside researcher: as Johns put it: "Every student a Sherlock Holmes" (Johns, 2002, p. 105).

It boosts confidence in one's written production for it would appear on the same footing to an authentic text composed by a native expert.

It promotes communication and collaboration among students when looking up at different lexical patterns in comparison.

It fosters metacognitive skills as required in that stage of learning (Anthony, 2019).

2.3. DDL Application Challenges.

With all virtues of the innovative approach, corpus data demotivates the learners; it offers rather a "condensed exposure" that confuses them (as non-linguists) (Gabrielatos, 2005, p. 10), and therefore they refrain from proceeding to adopt the corpus tools in classrooms. Moreover, beginners and low-intermediate students may strive at composing texts with correct spelling and grammar for which adding phraseological knowledge demoralizes their learning. And if students are still stuck at basic vocabulary knowledge, we should never entangle them with more 
sophisticated information (Kilgarriff, Marcowitz, Smith, \& Thomas, 2015). Even with Tribble's examples of available corpus resources for EGP and EAP classrooms (Tribble, 2013), they are not user-friendly as a result of their inefficacy in using uncompromising technical interfaces. As such, Anthony (Anthony, 2019) enlisted unprecedented opportunity of enabling ESP students to create DIY corpora and sub-corpora based on their own academic specializations to further investigate sounds overwhelming to language students. They, especially undergraduates, may sooner get intimidated with "the sheer number of examples of different phenomenon presented to them" (Anthony, 2019, p. 236).

Vyatkina \& Boulton highlighted the real difficulty encountered in DDL pedagogical applications despite the promising case studies conducted. They contended that "one obvious obstacle is the non-transparent user interface of many available corpora.... requiring considerable levels of linguistic and technological sophistication (Vyatkina \& Boulton, 2017, p. 2). Notwithstanding, Tribble was so ambitious to claim that the more educators and students are aware of the corpora capabilities, the better chances of witnessing the approach integrating into a wider range within the learning process (Tribble, 2013).

In contrast to most encouraging western studies, some Asian researches have observed a lack of corpora-in-classroom viability. Zhi Quan, in a recent experimental study, sheds light on the conundrum of adopting corpora in EAP settings even with a seamless mobile technology (Quan, 2016). Students were supposed to use a corpus technology they are already familiar with to learn academic vocabulary. Surprisingly, they appeared reluctant and less appealed to DDL integration. Quan expounded on the disappointing results for that learners failed to cope with concordances on their own due to the "overload of examples" (Quan, 2016, p. 285). Typically, it is what SkELL is avoiding doing (see the following section for details).

\subsection{SKELL Web Corpus Tool}

This teaching-oriented corpus tool meets the criteria set by Braun (2005) as summarized in Timmis's Corpus Linguistics for Research and Practices in terms of: size, inter-textual coherence, proper annotation (SkELL is auto-tagged for grammatical and semantic identification), and feasible exploitation by the teacher (Timmis, 2015, p. 129). The webcorpus interface is made up of the large cloud-based processor of text collections, Sketch Engine, which is constructed essentially for linguistics and lexicographers. According to (Baisa \& Suchomel, 2014), the madeup pedagogic interface, SkELL, encompasses the same sophisticated computational technology the mother site runs on (p. 64). 
Concerning the included corpora that structure the SkELL, there are FIVE various resources: the British National Corpus (112 million words), Wikipedia (500 million words), Gutenberg (200 million words), White (500 million words), News \& Blogs (305 million words) - that count for more than a 1.6 billion-word collection (p. 68-69). Besides the state-of-art processing procedures cleaning, tagging, and compilation of SkELL corpus, they use a GDEX tool (stands for Good Dictionary Examples) to pick innovatively the most suitable example sentences (concordances) to the query entered by the learner. In other words, displayed authentic examples must be well-representing to what he/she is looking for.

Features of the SkELL web tool that can be reached and explored via www.skell.sketchengine.eu (for regular computer/tablet browsers) or www.skellm.sketchengine.co.uk (more convenient for mobile devices). According to (Baisa \& Suchomel, 2014; Kilgarriff, et al., 2015), the given features of the database are presented orderly and visually to the ELLs without disctracting or stressing them out with unneeded jargons or complicated figures. When we search for a word or a phrase in the search box, the features to investigate are basically: 1. Examples (up to 40 complete sentences with search item marked in red), 2. Collocations (or word sketch): they are categorized based on their grammatical relations to the search lexis (up to 15 in each category), 3. Thesuaras (of similar words - up to 40 in number): synonyms and close words in meaning are displayed in colorful and capturing wordclouds. See the figures below as an example of the noun choice.

Figure 1.1

Concordances of 'choice'

Choice 119.05 hits per million
choice
1. But are such " choices " free?
3. But sometimes tough choices mean starting difficult conversation within city government.
4. The format is 4 person captains choice.
5. One choice is credit card debt consolidation.
6. The choice was neither simple nor easy.
7. More formal news later once choices are made.
8. The 50 multiple choice bar exam questions are particularly difficult.
9. Financial success is achieved through choices made.
10. Party identification makes voting choice really simple.


Fig. 1.2

Word Sketch of 'choice'

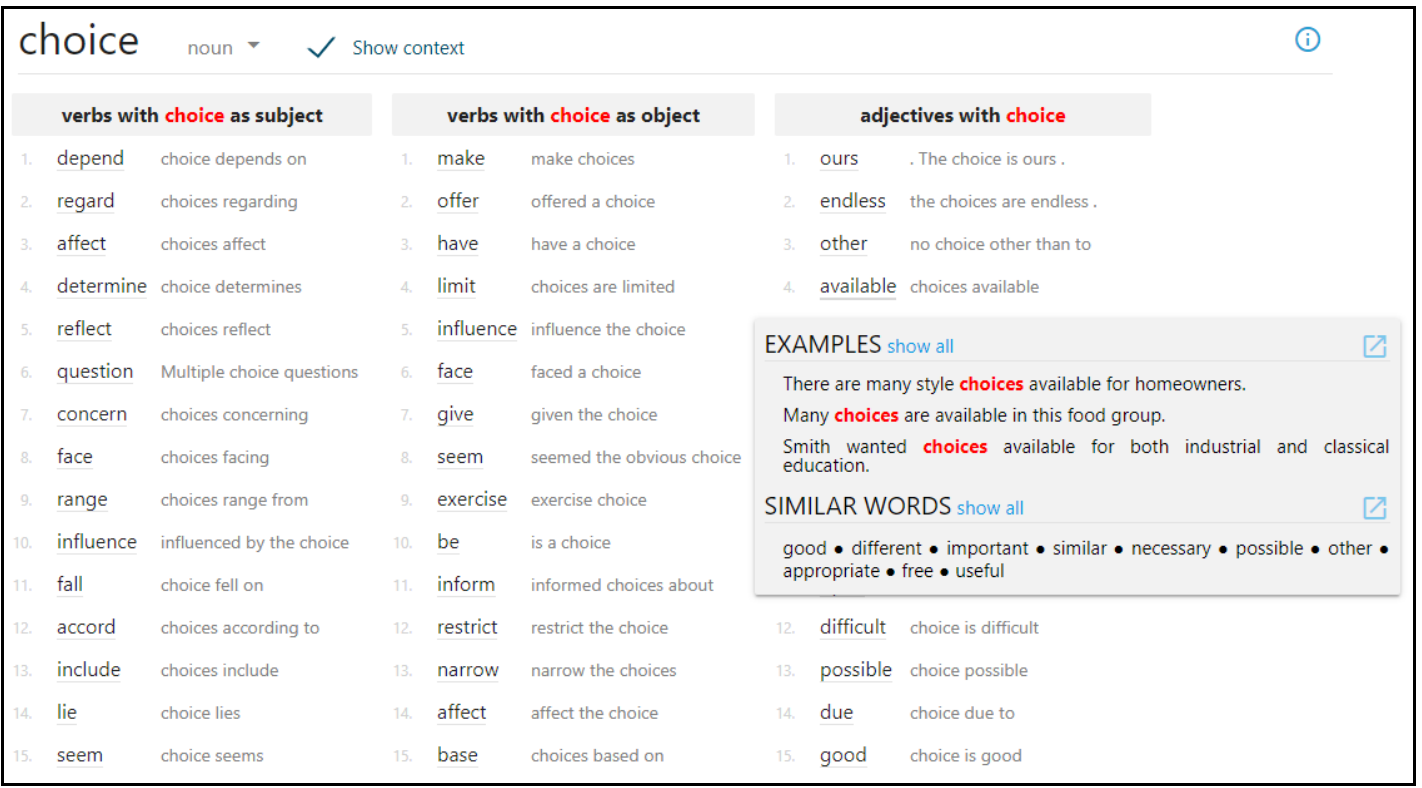

Fig. 1.3

Similar Words of 'Transport'

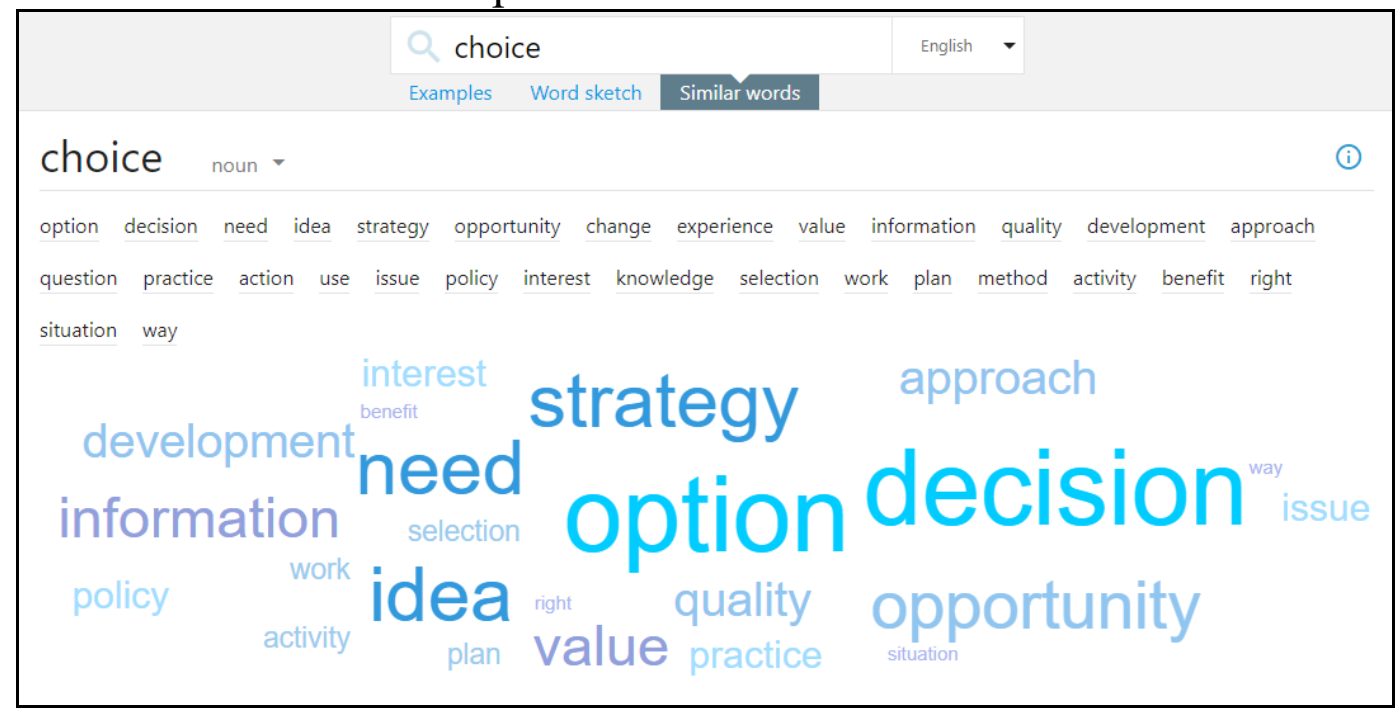

After taking a bird-eye view of the SkELL build and potentials, we can add to the eight given advantages of corpus tools in classrooms mentioned earlier in this paper (see section 202), we can add a significant benefit to the web app in an EAP classroom:

It provides a pedagogically safer environment for students than other concordancers which tend to be "off-putting" (Gilquin \& Granger, 2010, p. 367) or in Killgraff et al.'s term "scaring to students" (Kilgarriff, Marcowitz, Smith, \& Thomas, 2015).

It presents a mobile experience for low-tech classroom settings and more reliable service of cloud-based processing/monitoring without breaking 
students' devices. All students need is a mobile device, an internet connectivity, and enthusiasm to research.

\section{Design \& Procedure}

Since our purpose, in perspective of the current research, is to establish a framework on which academic writing is presented in college settings, therefore, choosing the right ELT corpus, at the first hand, is crucial; McCarten argued that "different corpora will give us different words and often different uses of words to teach" (McCarten, 2007, p. 2). Another significant point to consider is that it should acknowledge the teacher reality of being either too busy to carefully pick and upload whichever suitable corpora or tech-savvy no more to deal with a concordancer designed mainly to serve linguists and lexicographers; otherwise, we add a further burden on the educator's shoulders during the learning process.

Alternatively, we build our model on three main facts: 1 . Deploying a seamless corpus solution of the cloud-based 4th generation (almost no technical issue is expected) with a pre-loaded NS corpus, and 2. Applying the DDL approach along with the regular teaching methods and strategies (task-based and discovery learning are to adopt) with no role alteration; exploring authentic texts in the corpus becomes supplementary in the writing process, 3 . the given-access technology (personal smartphones, tablets, etc.) of enables ELLs to individualize their learning without the need of conducting serious tutorial sessions before the actual writing class. Thus, the outcome model would underpin both the teacher and the learner to achieve near-native versions of writing.

Based on Scrivener's framework (2011, p. 232) which applies process writing inductively, the study suggests an integration of the datadriven learning approach in a teacher-led to student-led model. Accordingly, the given writing model would function advantageously as previously mentioned in section 2.2. To reflect on our corpus-informed writing model, we use a writing prompt from task 2 example of an academic IELTS test. Then, we develop a writing session as task-based in which apprentices are to investigate (with the help of SkELL) relevant vocabulary and related formulaic language to include before jotting down their written production. Activities, so far, adhere to the corpora bottomup features (we start with single lexical units before moving to phraseological mode) as well as the conventional top-town mode in terms of organization and essay structure in a writing class.

4. New DDL Writing Model Using SkELL

In this section, we explain our writing model for EAP students in terms of 1. tasks \& their related skills to develop, 2. suggested classroom setting 
and requirement, 3. stages of delivery (pre, while, and post-teaching modes), and 4. teacher-learner concerns. To bear in mind, nevertheless, teachers should familiarize themselves well with the corpus database and different features through which they will let their students explore fully fledged texts autonomously and confidently in a while.

Firstly, throughout the DDL tasks demonstrated in SkELL, EAP trainees will be able to do and reinforce the following:

Table 1.

SkELL Corpus Tasks vs Cognitive and Language Skills to Develop

\begin{tabular}{lll}
\hline Corpus-oriented Tasks & \multicolumn{3}{c}{ Cognitive/Language Skills } \\
\hline $\begin{array}{l}\text { Identify word/phrase } \\
\text { (thesaurus feature) }\end{array}$ & alternatives & $\begin{array}{l}\text { Broaden their vocabulary power and } \\
\text { deepen their knowledge of semantic } \\
\text { relations }\end{array}$
\end{tabular}

Identify related topics to include under Support learners in brainstorming related the search word (thesaurus feature) ideas to the main writing topic

Explore phraseological varieties of the Develop efficient observational, lookup (word sketch engine feature) analytical, and constructional capacities of the text to render

Identify linguistic specificities of item use in real contexts (Examples feature)
Develop meta-cognitive skills towards the authentic/typical usage of lexes

Investigate the part-of-speech variations of single words in relation to phraseological patterns they construct with other words (word sketch and examples)

Discuss in pairs/groups different formulaic findings and share their written sentences that match authentic examples provided (all SkELL features)

In our model, no sophisticated requisites are expected; for that, student dictionaries (paper or mobile; e.g. Google Translate app), and a teacher's data show projector to thoroughly consider corpus examples. It is recommended that the teacher explores key concepts of the writing topic before class. He/She should also prepare some guiding questions to underpin students' learning by observation and pique their interest in the corpus tool and in research in general. The instructor is free to direct more concept checking questions or adopt more activities to conceptualize paradigmatic uses of language items. However, students are only encouraged to investigate the key ideas to include (maximally 4 
or 5) a short essay writing 250-300 words long; otherwise, there will not be time for productive writing. Nevertheless, a second draft to do as a homework assignment would unleash our students' researcher instinct more naturally and autonomously.

In an IELTS academic writing example (Cambridge University Press, 2017, p. 93), we illustrate here this framework in agreement with taskbased / discovery learning approaches. Students are supposed to write a short essay about the following academic topic children and making decisions:

Some people believe that allowing children to make their own choices on everyday matters (such as food, clothes and entertainment) is likely to result in a society of individuals who only think about their own wishes. Other people believe that it is important for children to make decisions about matters that affect them.

Discuss both these views and give your own opinion.

Following Scrivener's model of classroom writing (Scrivener, 2011, p. 237), the DDL approach can be actively integrated. See the table below. Table 1

Proposed Teaching Model for Adult Writing Class

\begin{tabular}{|c|c|c|c|}
\hline Stage & Materials & $\begin{array}{l}\text { Method of } \\
\text { Interaction }\end{array}$ & Description \\
\hline $\begin{array}{l}\text { Introduce the } \\
\text { Topic }\end{array}$ & Board/pictures/flashcards & T-Ss & $\begin{array}{l}\text { Use the conventional ways of } \\
\text { leading students in the topic, } \\
\text { e.g. discussing some key issues. }\end{array}$ \\
\hline $\begin{array}{l}\text { Summarize the } \\
\text { Writing Task } \\
\text { (what \& how) }\end{array}$ & Board/Sample outcome & T-Ss & $\begin{array}{l}\text { Inform your students about the } \\
\text { writing task genre (essay, } \\
\text { report, etc.). Clarify the purpose } \\
\text { and target structure. }\end{array}$ \\
\hline $\begin{array}{l}\text { Brainstorm } \\
\text { ideas }\end{array}$ & $\begin{array}{l}\text { Board/ SkELL similar } \\
\text { words section }\end{array}$ & $\begin{array}{l}\text { T-Ss/S-S/ } \\
\text { Ss-T }\end{array}$ & $\begin{array}{l}\text { Collect as many ideas as } \\
\text { possible, on the board. Have } \\
\text { them discuss in pairs/groups } \\
\text { first. You may use the 'similar } \\
\text { words' section in SkELL to } \\
\text { view some prompts related to } \\
\text { the main topic. For example, } \\
\text { 'decision' making may bring } \\
\text { ideas of 'information',, } \\
\text { 'authority', 'requirement', } \\
\text { 'change', etc. }\end{array}$ \\
\hline $\begin{array}{l}\text { Select, reject } \\
\text { and order ideas }\end{array}$ & Board/ worksheets & S-S/Ss-T & $\begin{array}{l}\text { Students decide, in pairs/groups, } \\
\text { which ideas to include/reject, } \\
\text { and how to fit them in the } \\
\text { written product. They must be } \\
\text { critical if opposing views are to } \\
\text { discuss. }\end{array}$ \\
\hline
\end{tabular}




\begin{tabular}{|c|c|c|c|}
\hline Stage & Materials & $\begin{array}{l}\text { Method of } \\
\text { Interaction }\end{array}$ & Description \\
\hline $\begin{array}{l}\text { Review } \\
\text { Language } \\
\text { Requirements }\end{array}$ & $\begin{array}{l}\text { Board/ Worksheets / } \\
\text { SkELL examples section }\end{array}$ & $\mathrm{T}-\mathrm{Ss} / \mathrm{S}-\mathrm{S}$ & $\begin{array}{l}\text { Provide / Review academic } \\
\text { vocabulary/ structure to adopt, } \\
\text { e.g. AWL, subordination, etc. } \\
\text { Use authentic example } \\
\text { sentences from SkELL around } \\
\text { the topic. Guide them with } \\
\text { CCQs to reinforce. }\end{array}$ \\
\hline $\begin{array}{ll}\text { Focus } & \text { on } \\
\text { Language } & \end{array}$ & $\begin{array}{l}\text { Worksheets / Dictionary/ } \\
\text { SkELL word sketch and } \\
\text { examples sections }\end{array}$ & S-S/T-Ss & $\begin{array}{l}\text { Provide some example } \\
\text { sentences around a single key } \\
\text { idea (in worksheets). And guide } \\
\text { them to explore their formulaic } \\
\text { patterns through Q\&A. Let } \\
\text { them use the dictionary for new } \\
\text { words. Instruct them on SkELL } \\
\text { website on board by } \\
\text { investigating grammatical } \\
\text { attributes of a certain keyword } \\
\text { before showing some sentence } \\
\text { examples of a phrase you/they } \\
\text { pick. }\end{array}$ \\
\hline $\begin{array}{l}\text { Practice Key } \\
\text { Sentence } \\
\text { Writing }\end{array}$ & $\begin{array}{l}\text { Worksheets / Dictionary/ } \\
\text { SkELL (on students' } \\
\text { smart devices) }\end{array}$ & $\mathrm{S}-\mathrm{S}$ & $\begin{array}{l}\text { Let students } \\
\text { autonomously or in groups to } \\
\text { explore some more words or } \\
\text { pattern uses. Guide them } \\
\text { individually if necessary. }\end{array}$ \\
\hline Draft 1 & $\begin{array}{l}\text { Worksheets / Dictionary/ } \\
\text { SkELL (on students' } \\
\text { smart devices) }\end{array}$ & $\begin{array}{l}\text { Individual } \\
\text { Work }\end{array}$ & $\begin{array}{l}\text { Have them worked individually } \\
\text { to render the first draft. }\end{array}$ \\
\hline Edit & $\begin{array}{l}\text { Worksheets / Dictionary/ } \\
\text { SkELL (on students' } \\
\text { smart devices) }\end{array}$ & $\mathrm{S}-\mathrm{S} / \mathrm{T}-\mathrm{Ss}$ & $\begin{array}{l}\text { Let them group-edit following a } \\
\text { proofreading checklist }\end{array}$ \\
\hline Feedback & $\begin{array}{l}\text { Worksheets / Dictionary/ } \\
\text { SkELL (on board) }\end{array}$ & S-S/Ss-T & $\begin{array}{l}\text { In groups, comment evidentially } \\
\text { on their writings. Discuss } \\
\text { possible ways to render better } \\
\text { production. }\end{array}$ \\
\hline $\begin{array}{l}\text { Assignment } \\
\text { (Final Draft) }\end{array}$ & Worksheets / Notes & $\begin{array}{l}\text { Individual } \\
\text { Work }\end{array}$ & $\begin{array}{l}\text { Give students time to work on } \\
\text { their own outside the classroom } \\
\text { and produce a better revised } \\
\text { piece of writing. }\end{array}$ \\
\hline
\end{tabular}

To expound upon the above table, the teacher applies initially a traditional top-down strategy in introducing the topic and discussing related ideas with students. Subsequently, the DDL bottom-up strategy empowers students to investigate word/phrase level before moving to more constructive forms of writing with support of corpora. Those two stages typically represent the framework of the DDL-based model. We make sure that the corpora presentation is performed in disguise, with gradual and purposeful appearance to the ELLs as the literature suggests. 
SkELL does not appear until the third stage (Brainstorming of ideas) as an optional prevalence to support students' idea productivity about the main topic. By using the 'similar words' section to generate related semantic relations such as authority, requirement, change, which stimulate related ideas to the central one: decision making (see figures $1.1,1.2, \& 1.3)$. Ideas are displayed in an appealing color-coded cloud that can be an encouraging start for visual learners nowadays. Further, the SkELL feature suggests synonymous words for to the learner, e.g. plan, action, choice. Therefore, we are supposed to guide students through observing the two vocabulary sets to benefit from in their writing. A teacher may ask:

What are alternative words to use?

What are the possible supporting ideas to the topic?

The second contact to the SkELL corpora comes in the 5th \& 6th stages after schematic and organizational formats of the essay are thoroughly discussed.

Students may come across the verb confine (an academic [transitive] verb for limit or restrict) to refer to social groups who have the right to make decisions. Identifying the dictionary meaning of the verb does not help in recognizing its contextual forms. Thus, the teacher would encourage his/her students to explore some linguistic attributes of the verb use by directing questions like:

Is the verb followed by on or to?

Is it commonly used in active or passive voice?

Language apprentices should now use the SkELL examples feature on their mobile browsers to answer those questions. They should then be able to recognize the dictionary untold aspects and ultimately achieve a near-native speaker's production.

For the purpose of creating a healthy research atmosphere, the teacher can divide students in two large groups, each adopts an opposite stand of children making their own choices. They may be further divided into smaller groups or pairs to share their sentences based on what they are oriented about in steps $5 \& 6$. Once they are comfortable with the SkELL searches, the teacher can move them upward to compose their first draft, individually. At that point, each young researcher is now equipped with the right tools to enhance his/her writing skills: a dictionary and a corpus concordancer. 


\section{The Use of an Open Access Corpus Web Tool in a DDL Writing Model}

5. Conclusion and Future Studies

In this paper, we introduce an innovative writing model for EFL academic classrooms. Its efficiency is attributable primarily to the teacher's role as a facilitator and a research team leader. We demonstrate the corpora's advantageous aspects in enhancing learning and supporting intuitively the ELLs' produced formulaic language. We tried to highlight the previous efforts and challenges of adopting corpora in ESL/EFL classrooms. However, with the advent of cloud-based technology and enormous leaps the world is witnessing in the computational fields at the moment, it becomes natural to rely on such technology in language learning. If the current research proposes a model to deploy by EAP students seamlessly, we believe that future research may bring other innovative methods and tools to support younger students' learning. 


\section{References}

Anthony, L. (2019). Tools and Strategies for Data-Driven Learning (DDL) in the EAP Writing Classroom. In K. Hyland, \& L. Wong, Specialised English: New Directions in ESP and EAP Research and Practice (pp. 231-249). Routledge. doi:10.4324/9780429492082-14

Anthony, L., Flowerdew, J., \& Costley, T. (2016). Introducing corpora and corpus tools into the technical writing classroom through Data-Driven Learning (DDL). In J. Flowerdew, \& T. Costley, Discipline Specific Writing: Theory into Practice (pp. 162-180). Routledge. doi:10.4324/9781315519012

Baisa, V., \& Suchomel, V. (2014). SkELL: Web Interface for English Language Learning. In A. Horák, \& R. P. (Ed.), Recent Advances in Slavonic Natural Language Processing, RASLAN, (pp. 63-70). doi:10.1002/j.19419635.2014.tb01202.x

Cambridge University Press. (2017). Cambridge IELTS 12 Academic Module Student's Book With Answers. London: Cambridge University Press.

Durrant, P., \& Schmitt, N. (2009). To What Extent Do Native and Non-Native Writers Make Use of Collocations? IRAL-International Review of Applied Linguistics in Language Teaching, 157-177. doi:10.1515/iral.2009.007

Flowerdew, J., \& Costley, T. (. (2016). Discipline-Specific Writing: Theory into Practice. Taylor \& Francis. doi:10.4324/9780429492082-14

Gabrielatos, C. (2005). Corpora and Language Teaching: Just a Fling or Wedding Bells? The Electronic Journal for English as a Second Language. Retrieved from https://eric.ed.gov/?id=EJ1068106

Gilquin, G., \& Granger, S. (2010). How can data-driven learning be used in language teaching? In A. O'Keeffe, \& M. McCarthy, The Routledge handbook of corpus linguistics (pp. 387-398). Routledge. doi:10.4324/9780203856949.ch26

Hyland, K. (2006). English for Academic Purposes: An Advanced Resource Book. Routledge.

Johns, T. (1994). From printout to handout: Grammar and vocabulary teaching in the context of Data-driven Learning. In $T$. Odlin, Perspectives on Pedagogical Grammar (pp. 293-310). Cambridge University Press. doi:10.1017/CBO9781139524605.014

Johns, T. (2002). Data-driven learning: The perpetual challenge. In B. Kettemann, \& G. Marko, Teaching and learning by doing corpus analysis (pp. 105-117). Brill Rodopi. doi:10.1163/9789004334236_010

Kilgarriff, A., Marcowitz, F., Smith, S., \& Thomas, J. (2015). Corpora and Language Learning with the Sketch Engine and SKELL. Revue française de linguistique appliquée, 61-80. doi:10.3917/rfla.201.0061

Koosha, M., \& Jafarpour, A. A. (2006). Data-driven learning and teaching collocation of prepositions: The case of Iranian EFL adult learners. Asian EFL journal, 192-209.

Mao, L., Liu, Y., \& Zhang, M. (2018). Research on the Effectiveness of College Student English Writing Teaching Based on Data-Driven Learning. 
The Use of an Open Access Corpus Web Tool in a DDL Writing Model

Educational Sciences: Theory \& Practice, 1160-1169. doi:10.12738/estp.2018.5.017

McCarten, J. (2007). Teaching Vocabulary: Lessons from the Corpus, Lessons for the Classroom. Cambridge University Press. doi:10.14393/DL15v8n1a2014-39

Nesselhauf, N. (2004). Learner corpora and their potential for language teaching. In J. Sinclair, How to use corpora in language teaching (pp. 125-156). John Benjamins. doi:10.1075/scl.12.11nes

O'keeffe, A., McCarthy, M., \& Carter, R. (2007). From corpus to classroom: Language use and language teaching. London: Cambridge University Press. doi:10.1017/CBO9780511497650

Quan, Z. (2016). Introducing "mobile DDL (data-driven learning)" for vocabulary learning: an experiment for academic English. Journal of Computers in Education, 273-287. doi:10.1007/s40692-016-0067-0

Schmitt, N., Sonbul, S., Vilkaitė-Lozdienè, L., \& Macis, M. (2013). Formulaic language and collocation. In C. Chapelle, The Encyclopedia of Applied

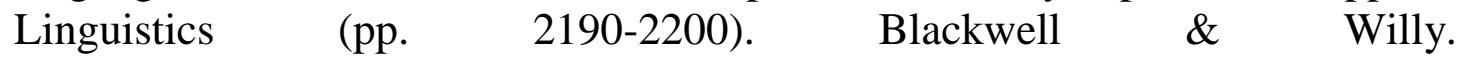
doi:10.1002/9781405198431.wbeal0433.pub2

Scrivener, J. (2011). Learning teaching: The essential guide to English language teaching. Macmillan.

Scrivener, J. (2014). 4 DEMAND-HIGH TEACHING. The European Journal of Applied Linguistics and TEFL, 47-59.

Silver, H. F., Dewing, R. T., \& Perini, M. J. (2012). The Core Six: Essential Strategies for Achieving Excellence with the Common Core. ASCD.

Timmis, I. (2015). Corpus linguistics for ELT: Research and practice. Routledge. doi:10.4324/9781315715537

Tribble, C. (2013). Corpora in the Language-Teaching Classroom. In C. A. (Ed.), The Encyclopedia of Applied Linguistics. Blackwell Publishing Ltd. doi:10.1002/9781405198431.wbeal0226

Vyatkina, N., \& Boulton, A. (2017). Corpora in language learning and teaching. Language. Language Learning \& Technology, 1-8. doi:10.1002/9781118784235.eelt0397 